\title{
Analisis Strategi Pemasaran untuk Meningkatkan Pendapatan UMKM
}

\author{
(Studi Kasus pada UMKM MITA )
}

\author{
Manajemen Pemasaran
}

Ery Suryanti $^{1 *}$, Hendra lesmana ${ }^{2)}$, Husni Mubarok ${ }^{3)}$

Sistem Informasi Akuntansi, Universitas Bina Sarana Informatika

*Email: erisuryanti.esi@bsi.ac.id

\begin{abstract}
Abstrak
Pemasaran adalah suatu kegiatan dimana pelaku usaha menawarkan produknya kepada konsumen agar dapat menerima produk tersebut dengan segala ide dan gagasan agar produk tersebut dapat diminati oleh konsuman. Pemasaran merupakan unsur yang penting yang harus diperhatikan sehingga sesuai dengan harapan, yaitu mendapatkan konsumen yang diharapkan. Berbagai jenis macam UMKM yang berdiri dan berbagai macam jenis produk yang ditawarkan dari semua yang ada hampir sama karena produk UMKM mudah untuk di buat dengan bahan yang tidak begitu mahal harganya.. Dari banyaknya jenis produk yang ada UMKM perlu adanya inovasi yang lebih kreatif agar konsumen bisa tertarik karena yang ada jenis produk yang hampir setiap hari sama sehingga disini perlu adanya keberanian untuk menciptakan produk yang tidak bisa tersaingi. Dengan menggunakan analisa SWOT dapat mengetahui bagaimana strategi pemasaran yang tepat sasaran. Meliputi Faktor internal yaitu kekuaatan dan kelemahan serta faktor eksternal yaitu peluang dan ancaman yang dimiliki UMKM. Serta mengetahui tujuan strategi pemasaran yang digunakan sehingga dapat meningkatkan pendapatan dengan banyaknya konsumen yang tertarik pada produk yang dijual. Tehnik pengumpulan data melalui dokumentasi, wawancara dan observasi. Tehnik analisis data menggunakan riset dokumentasi dan analisis deskriptif.
\end{abstract}

\section{Kata Kunci : Strategi Pemasaran, UMKM, Pendapatan}

\begin{abstract}
Abstrack
Marketing is an activity in which a business actor offers his product to consumers in order to receive the product with all ideas and ideas so that the product can be sought after by consumers. Marketing is an important element that must be considered so that it is in line with expectations, which is to get the expected consumers. Various types of MSMEs that stand and various types of products offered from all that exist are almost the same because MSME products are easy to make with materials that are not so expensive. Of the many types of products that exist MSMEs need more creative innovation so consumers can be interested because there are types of products that are almost every day the same so here it is necessary to have the courage to create products that cannot be competed. Using a SWOT analysis can find out how the marketing strategy is right on target. Includes internal factors, namely strengths and weaknesses and external factors, namely opportunities and threats that are owned by MSMEs. As well as knowing the objectives of the marketing strategy used so that it can increase revenue with many consumers interested in the product being sold. Data collection techniques through documentation, interviews and observations. Data analysis techniques used research documentation and descriptive analysis.
\end{abstract}

Keywords: Marketing Strategy, MSME, Revenue 


\section{PENDAHULUAN}

Tujuan dari pembangunan ekonami nasional adalah terciptanya masyarakat adil dan makmur. Tujuan dari pembangunan ekonomi nasional mampu menggerakkan laju perekonomian salah satunya adalah UMKM. Indonesia merupakan negara yang tingkat kesuburan tanah jauh lebih subur di bandingkan negara negara lain. Banyak tanaman yang tumbuh yang dapat dikonsumsi maupun untuk di jual. Dari hasil produk tanaman tersebut banyak yang diolah untuk menjadi sebuah produk makanan atau minuman yang dapat di jual sehingga banyak muncul UMKM di daerah daerah karena usaha tersebut tidak memerlukan bahan bahan yang harus di impor. Sehingga banyaknya UMKM berdiri maka laju perekonomian berjalan dengan baik. Bahkan sektor UMKM ini mampu bertahan disetiap iklim dan disetiap waktu saat sekarang terjadi pandemi corona UMKM sanggup bertahan. Ide dan gagasan banyak bermunculan sehingga timbul berbagai macam bentuk usaha dengan hasil yang mereka rasakan mampu bertahan. Berdirinya UMKM ini mampu mengurangi jumlah pengangguran dan dapat menyerap sejumlah pekerja sehingga mengurangi jumlah urbanisasi.

UMKM pada awalnya adalah usaha dengan modal sendiri tapi para pelaku usaha UMKM mampu bersaing dengan yang lainnya dan mampu bertahan walaupun saat usahanya jatuhpun mereka bisa bangkit walaupun dengan modal awal milik sendiri. Sifat kekeluargaan inilah yang mampu membuat usaha UMKM ini bertahan dengan berbagai permasalahan yang dihadapi saat mulainnya usaha sampai akhirnya mendapatkan keuntungan maka keluargalah yang akan merasakan dampak dari usaha tersebut. Tidak semua UMKM diawali dengan sukses banyak dari mereka harus jatuh bangun terlebih dahalu untuk mendapatkan kesuksesan. Namun banyak kendala yang di hadapi oleh UMKM MITA yaitu belum memiliki tempat untuk menjual produk kue. Untuk sementara ke- giatan penjualan produk kue masih di rumah. Karena saat ini UMKM MITA belum memiliki Toko kue yang tempatnya strategis.dan hanya memiliki dua kendaraan sepeda motor untuk mendistribusikan ke tempat tempat yang jaraknya sangat jauh dari tempat usaha. UMKM MITA yang memiliki usaha memproduksi aneka macam snack dan catering. UMKM MITA sudah lama berjalan masih perlu pembenahan baik dalam administrasi keuangan ataupun dengan strategi pemasarannya karena banyaknya UMKM yang ada saat ini. Bahkan banyak usaha yang sama dengan harga yang tidak jauh berbeda dengan adanya persaingan maka usaha UMKM ini perlu adanya konsep atau tindakan agar UMKM tetap berjalan.

Pemasaran merupakan suatu yang harus diperhatikan dalam kita menjalankan suatu usaha, pemasaran sangat penting untuk bisa mengembangkan usaha agar lebih maju sehingga perlu adanya berbagai strategi dan konsep agar pemasaran dapat tertuju atau tercapai sesuai dengan keinginan. Manajemen pemasaran merupakan strategi yang dimiliki perusahaan. Agar mendapatkan laba yang diinginkan maka pemasarannya harus mengena pada yang dituju sehingga akan tercapai dan akan mendapakan hasil yang sesuai dengan keinginan. Perlu adanya taktik yang jitu seorang pelaku usaha dengan segala usahanya agar pemasaran yang dijalankan sesuai dengan keinginannya. Tanpa adanya bidang pemasaran makan penjualan tidak akan sesuai dengan keinginan, pemasaran perlu diolah dengan pemikiran yang matang dan disesuaikan dengan keinginan pasar saat ini.

\section{TINJAUAN PUSTAKA}

\section{Pengertian UMKM}

UMKM adalah usaha perdagangan yang di kelola oleh badan usaha atau perorangan yang berunjuk pada usaha ekonomi produktif. Usaha Mikro adalah usaha yang dilakukan seseorang biasanya dilakukan dengan tujuan penenuhan kebutuan. 
Sehingga untuk memenuhi kebutuhan orang melakukan usaha mikro. dalam undang-undang ini. Adapun penghasilan usaha ini maks 50 juta, omzet maks 300 juta rupiah.

Usaha kecil adalah usaha ekonomi produktif yang berdiri sendiri yang dijalankan oleh orang perorangan atau badan usaha bukan merupakan perusahaan atau cabang atau anak perusahaan yang pengelolaannya masih sangat sederhana baik dari manajeman maupun dari pruduksinya. Baik secara langsung maupun tidak langsung dari usaha menengah atau usaha besar yang memenuhi kriteria usaha kecil sebagaimana dimaksud dalam undang undang ini. Kriteria asset 50juta- 500 juta, kriteria omzet yang dihasilkan 300 juta 2,5 Miliar rupiah.

Usaha menengah adalah usaha yang mulai ada perkembangan dari usaha kecil ke usaha menengah dimana usaha ini sudah ada penambahan modal dan tenahga kerja sehingga omzetpun bertambah. Kriteria asset 500 juta -10 miliar, kriteria omzet >2,5 miliar -50 miliar rupiah.

Tabel 1. Undang-undang dan peraturan UMKM

\begin{tabular}{|l|l|l|}
\hline No & \multicolumn{3}{|c|}{ Undang undang atau PP } \\
\hline 1 & $\begin{array}{l}\text { UU No.9 Tahun 1995 tentang } \\
\text { usaha kecil }\end{array}$ \\
\hline 2 & $\begin{array}{l}\text { PP No. 44 Tahun 1997 tentang } \\
\text { kemitraan }\end{array}$ \\
\hline 3 & $\begin{array}{l}\text { PP No. 32 Tahun 1998 tentang } \\
\text { pembinaan dan usaha kecil }\end{array}$ \\
\hline 4 & $\begin{array}{l}\text { Kepres No. 56 tahun 2002 tentang } \\
\text { restrukturisasi usaha kecil dan } \\
\text { menengah }\end{array}$ \\
\hline 5 & $\begin{array}{l}\text { Permenneg Per } \\
\text { 05/MBU/2007 tentang program } \\
\text { kemitraan badan usaha milik negara }\end{array}$ \\
\hline 6 & $\begin{array}{l}\text { UU No. 20 Tahun 2008 tentang } \\
\text { UMKM }\end{array}$ \\
\hline
\end{tabular}

\section{Klasifikasi UMKM}

Dalam perspektif perkembangan UMKM dapat di klasifikasikan menjadi 4 kelompok : a. Livelihood Activities merupakan UMKM yang digunakan ebagai kesempatan kerja untuk mencari nafkah yang lebih umum dikenal sebagai sektor informal.

b. Micro Enterprise merupakan UMKM yang memiliki sifat pengrajin tetapi belum memiliki sifat kewirausahaan

c. Small dynamic enterprise merupakan UMKM berjiwa kewirausahaan dan sudah berkembang dapat melaksanakan kegiatan eksport.

d. Fast moving enterprise merupakan UMKM yang telah memiliki jiwa kewirausahaan dan melakukan transformasi menjadi usaha besar.

\section{World Bank, membagi UMKM ke da-} lam 3 jenis yaitu

a. Medium enterprise dengan banyaknya karyawan dengan jumlah maksimal 300 orang. Akan menghasilkan pendapatan setahun hingga sejumlah $\$ 15$ juta.

b. Small enterprise dengan karyawannya jauh dari jumlah Mediun enterprise kalau small enterprise jumlah karyawan 30 orang, pendapatan setahun hingga sejumlah $\$ 3$ juta,.

c. Micro enterprise dengan jumlah karyawan maksimal 10 orang bahkan kadang belum memiliki karyawan, usaha yang dijalankan dikerjakan sendiri. Adapun jumlah pendapatan setahun hingga sejumlah $\$ 100$ ribu.

\section{Ciri- ciri UMKM}

a. Jenis komoditi/barang pada usahanya tidak tetap, atau bisa berganti sewaktu waktu.

b. Tempat menjalankan usahannya bisa berpindah pindah sewaktu waktu.

c. Usahanya belum menerapkan administrasi bahkan keuangan pribadi dan usaha masih disatukan. 
d. Sumber daya manusia (SDM) di dalamnya belum memiliki jiwa kewirausahaan.

e. Biasanya tingkat pendidikan SDM nya masih rendah.

f. Pada umumnya belum memiliki surat ijin usaha atau legalitas termasuk NPWP.

Berdasarkan kriteria dan ciri ciri UMKM diatas maka dapat diambil kesimpulan bahwa UMKM adalah usaha yang dikelola oleh individu atau badan usaha di bidang perdagangan. Dengan banyaknya UMKM yang berdiri maka akan turut mengembangkan perekonomian nasional. Banyaknya usaha yang di kelola perorangan ataupun badan usaha juga dapat mengurangi tingkat penganguran namun perlu adanya bantuan ataupun pelatihan pada UMKM agar tetap berjalan sehingga perkembangan perekonomian yang ada tetap maju. Perkembangan perekonomian juga tidak hanya bantuan ataupun pelatihan namun perlu adanya wadah yang membuat UMKM ini tetap berjalan. Usaha UMKM perlu adanya pembinaan agar ada peningkatan sehingga waktu demi waktu ada perkembangan yang baik dari usaha tersebut.

\section{Kriteria jenia usaha berdasarkan jum- lah tenaga kerja}

Kriteria jumlah karyawan berdasarkan jumlah tenaga kerja merupakan suatu tolak ukur yang digunakan oleh Badan Pusat Statistik untuk menilai suatu usaha kecil atau besar.

Tabel 2. Kriteria Usaha

\begin{tabular}{|l|l|l|l|}
\hline & $\begin{array}{l}\text { Usaha } \\
\text { mikro }\end{array}$ & $\begin{array}{l}\text { Usaha } \\
\text { kecil }\end{array}$ & $\begin{array}{l}\text { Usaha } \\
\text { menengah }\end{array}$ \\
\hline $\begin{array}{l}\text { Jumlah } \\
\text { tenaga } \\
\text { kerja }\end{array}$ & $<>$ & $\begin{array}{l}5-19 \\
\text { orang }\end{array}$ & $\begin{array}{l}20-99 \\
\text { orang }\end{array}$ \\
\hline
\end{tabular}

\section{Pengertian Strategi Pemasaran}

Menerapkan strategi pemasaran diawali dengan menganalisa secara keseluruhan dari situasi perusahaan. Pemasaran harus melakukan analisa SWOT dimana dapat menilai kekuatan (Strength), meliputi kemampuan internal, sumber daya dan faktor situasional positif yang dapat membantu perusahaan melayani pelanggannya dan mencapai tujuan. Kelemahan (Weaknesses), meliputi keterbatasan internal dan faktor situasional negatif yang dapat menghalangi performa perusahaan. Peluang (opportunities), faktor yang menguntungkan pada lingkungan eksternal yang dapat digunakan untuk memperoleh keuntungan. dan ancaman (Threats), faktor pada lingkungan eksternal yang tidak menguntungkan yang menghadirkan tantangan bagi performa perusahaan.

Dari hasil analisa SWOT maka perusahaan akan mengetahui bagaiman kondisi perusahaan apakah dalam keadaan yang baik atau tidak, bagaimana kekuatan perusahaan saat ini. Analisa ini juga akan mengetahui bagaimana kelemahan perusahaan sehingga dari kelemahan perusahaan akan terus berupaya untuk mengurangi kekurangan atau kelemahannya. Begitu juga dengan peluang. Bagamana perusaan akan mengambil peluang yang ada untuk meningkatkan pendapatan kegiatan ini juga dapat menambah jumlah laba perusahaan disamping perusahaan meemiliki peluang perusahaan juga memiliki ancaraman, agar perusahaan tetap berdiri dengan berbagai kekuatan yang di miliki maka ancaman dari luar tidak akan membuat perusahaan semaik turun dari segi pendapatan maupun dari bentuk usaha itu sendiri.

Menurut Amerikan Marketing asosiation, pemasaran adalah suatu proses perencanaan dan menjalankan konsep, promosi, harga dan distribusi sejumlah ide, barang, serta jasa, untuk menciptakan pertukaran yang dapat memuaskan tujuan organisasi dan individu. Pemasaran adalah suatu kegiatan yang menawarkan suatu 
produk kepada kensumen. Melalui proses yang melibatkan antara pelaku usaha UMKM dengan pihak lain yaitu konsumen. Produk yang dijual dapat diterima dan apa yang konsumen inginkan dapat terwujud, berbagai macam kegiatan penting yang memungkinkan perusahaan dan individu mendapatkan apa yang mereka butuhkan dan inginkan melalui pertukaran dengan pihak lain. Dari keterangan diatas dapat disimpulkan bahwa pemasaran merupakan kegiatan dimana produk yang di jual sangat di butuhkan pihak lain sehingga terjadi pembelian atau pertukaran. Dengan adanya pertukaran tersebut pembeli mendapatkan produk yang diinginkan serta perusahaan mendapatkan laba dari hasil penjualan.

Adapun penerapan strategi marketing melalui langkah langkah berikut

1. Segmentasi pasar (market segmentation) adalah tindakan pembagi pasar menjadi kelompok pembeli berbeda dengan kebutuhan, karakteristik. Menurut Saladin (2012:83) segmentasi pasar merupakan proses pengelompokan pasar kedalam kelompok pembeli. yang potensial dengan kebutuhan yang sama atau karakteristik yang disukai serta memperlihatkan hubungan yang sama pula. Dari segmentasi pasar ini mudah bagi perusahaan karena akan mengetahui produk yang di jual untuk kelompok pembeli antaralain: kelompok anak-anak, kelompok dewasa, kelompok orang tua atau untuk segala usia. Bahkan tidak hanya kelompok, produk yang di jual pun harus paham untuk kondisi atau iklim yang bagaimana, atau segala cuaca dan keadaan bisa diterima. Sehingga produk yang dijual tidak terpengaruh kelompok ataupun iklim yang ada.

Adapun variabel variabel yang dipakai dalam segmentasi pasar adalah

a. Segmentasi geografis membagi pasar menjadi unit secara geografis seperti kota, atau negara. b. Segmentasi demografis membagi pasar menjadi kelompok berdasarkan umur, pendapata dan pekerjaan.

c. Segmentasi psikorafik membagi pembeli berdasarkan kelas sosial dan gaya hidup.

d. Segmentasi perilaku membagi kelompok berdasarkan sikap, pengetahuan dan reaksi mereka terhadap suatu produk.

2. Penetapan target pasar (market targeting) adalah proses memilih target pasar yang akan dituju atau akan di fokuskan, dengan membangun hubungan yang baik sesuai target pasar maka sasaran akan tertuju, penetapan sasaran pasar terdiri dari perencanaan strategi yang matang dan tepat untuk membangun hubungan yang benar dengan pelangan yang tepat. Atau sebuah perusahaan besar mungkin memutuskan untuk menawarkan ragam produk yang lengkap dalam melayani seluruh segmen pasar sebagian besar perusahaan memasuki pasar baru dengan melayani segmen tunggal jika berhasil mereka akan menambah segmen. Menurut Tjiptono \& Chandra (2012:162) pengertian pasar sasaran adalah proses mengevaluasi dan memilih satu atau beberapa segmen pasar yang dinilai paling menarik untuk dilayani dengan program spesifik perusahaan. Dari pengertian tersebut dapat di pahami bahwa perusahaan harus bisa memilih segmen pasar yang di tuju dari segmen pasar tersebut dapat lebih menentukan spesifik segmen pasar yang akan di tuju kemudian.

3. Diferensiasi dan posisi pasar (Diferentiation \& positioning) merupakan kegiatan untuk mendapatkan pelanggan melalui segmen pasar yang di tawarkan oleh perusahaan. Segmn pasar yang dimiliki perusahaan akan membuat perusahan mendapatkan perhatian dari konsumen. Posisi duduk sebuag produk di pasaran akan semakin baik posisi yang tepat tertuju. Menurut Kotler 
(1997) pada dasarnya diferensiasi merupakan tindakan merancang satu set perbedaan yang berarti untuk membedakan penawaran perusahaan dan pesaing. Perusahaan dalam memilih pasar juga mampu untuk membedakan rancangan sendiri dan pesaing sehingga perusahaan dapat membedakan penawaran yang dimiliki dengan penawaran milik pesaing sehingga adanya perbedaan ini yang memudahkan perusahaan masuk dalam segmen pasar.

Setelah strategi pemasaran diterapkan maka perusahaan diharapkan menerapkan atau merancang bauran pemasaran (marketing Mix) terdiri dari 4P yaitu

1. Produk (product) merupakan kombinasi barang dan jasa yang ditawarkan perusahaan kepada pasar sasaran meliputi ragam, kualitas, desain, merk.

2. Harga (price) merupakan sejumlah uang yang harus dibayarkan pelanggan untuk memperoleh produk.

3. Tempat (place) merupakan kegiatan perusahaan yang membuat produk meliputi lokasi, persediaan.

4. Promosi (promotion) merupakan aktivitas yang menyampaikan atau membujuk pelanggan untuk membeli.

\section{Pengertian Pendapatan}

Pendapatan adalah jumlah uang yang dihasilkan dari suatu kegiatan atau usaha. Usaha yang dilakukan untuk sebuah hasil. Kegiatan menjual produk perusahaan ini yang nantinya di dapat merupakan pendapatan yang di terima walaupun harus dikurangi jumlah biaya yang sudah dikeluarkan untuk memproduksi barang dagang yang di jual. Sehingga pendapatan bersih perusahaan mudah diketahui. Dari hasil pendapatan tersebut maka akan terlihat laba rugi dari usaha tersebut.

Sumber pendapatan sangat penting bagi kegiatan usaha dari penerimaan jum- lah pendapatan sampai menghitung jumlah pengeluaran sangat penting maka dalam pencatatan atau penghitungan jangan sampai terjadi kesalahan. Untuk mengurangi kesalahan maka perlu adanya pencatatan yang baik. Pencatatan untuk pengeluaran dan pencatatan untuk pendapatan itu sendiri. Dari mulai memiliki usaha sampai berjalannya usaha perlu adanya pencatatan atau administrasi yang rapi, disamping perlunya administrasi diperlukan strategi agar pendapatan semakin bertambah sehingga mendapatkan laba yang lebih banyak.

Menurut Soemarsono (2003:130) pendapatan dalam perusahaan dapat dikelompokan menjadi dua, yakni

a. Pendapatan operasi adalah pendapatan yang diperoleh dari aktivitas utama perusahaan.

b. Pendapatan non operasi adalah pendapatan yang diperoleh selain kegiatan utama perusahaan.

Maka dari pengertian diatas dapat disimpulkan bahwa pendapatan utama perusahaan berasal dari kegiatan utama yaitu kegiatan pruduksi sehingga dari hasil penjualan tersebut maka akan mendapatkan laba sedangkan perusahaan tidak hanya memiliki pendapatan dari penjualan produk, namun bisa dari pendapatan selain penjualan. Penggunaan aktiva yang menghasilkan pendapatan perusahaan atau pembelian aktiva tetap yang nantinya dapat di jual kembali juga merupakan penambahan pendapatan.

Jenis-jenis pendapatan ;

a. Pendapatan yang diperoleh dari kegiatan utama perusahaan. Pendapatan yang diterima dari kegiatan rutin perusahaan atau kegiatan produksi perusahaan, kegiatan produksi perusahaan yang menghasilkan produk, produk terjual menghasilkan laba.

b. Pendapatan yang diperoleh dari luar usaha pokok perusahaan. Usaha sampingan perusahaan antara lain penyewaan kantor atau ruangan, 
penyewaan kendaraan perusahaan atau peralatan berat perusahaan.

\section{METODE PENELITIAN}

Penelitian deskriptif, metode yang digunakan dalam penelitian ini dengan menggunakan pendekatan kualitatif. Tempat penelitian dilaksakan di UMKM MITA, beralamat di Ds Pangkah Sabrang, Kec. Pangkah. Kab. Tegal. Tehnik pengumpulan data yang digunakan dalam penelitian ini adalah sebagai berikut :

1. Dokumentasi adalah tehnik yang digunakan untuk memperoleh informasi tentang aspek-aspek pendukung. Seperti jenis usaha serta jumlah laba yang di dapat.

2. Wawancara adalah percakapan dengan maksud tertentu. Terdiri dari dua orang yaitu orang yang bertanya dan orang yang menjawab.

3. Observasi adalah tehnik yang dilakukan langsung ke tempat penelitian.

Sedangkan Tehnik analisis data menggunakan metode deskriptif. Menurut Sugiono (2005:21) menyatakan bahwa metode deskriptif adalah suatu metode yang di dapat.yang digunakan untuk menggambarkan atau menganalisis suatu hasil penelitian tetapi tidak digunakan untuk membuat kesimpulan yang lebih luas.

\section{HASIL DAN PEMBAHASAN \\ Strategi pemasaran UMKM MITA}

UMKM MITA Menerapkan strategi pemasaran dengan menganalisa secara keseluruhan situasi pemasaran dengan melakukan analisa SWOT (SWOT analysis) untuk menilai kekuatan (strength), kelemahan (weaknesses), peluang (opportunities) dan ancaman (threats) secara keseluruhan.

\section{Analisa Faktor Internal}

a. Kekuatan perusahaan ( Strength)

Meliputi kemampuan internal atau sumber daya manusia dalam hal ini bagaimana usaha dapat berkembang dan laku dipasaran. Usaha kue dan catering ini mampu bertahan dengan bahan baku yang mudah dicari, dengan rasa yang paling enak dan unik yang akan di cari atau diterima di pasaran. Dengan adanya produk yang berkualitas maka konsumen mampu untuk memilih mana produk yang berkualitas mana yang tidak. Dengan bentuk dan takaran dari masing masing bahan yang akan menghasilkan produk kue ataupun produk masakan yang berkualitas dan rasa yang lezat maka akan cepat diterima di masyarakat. UMKM MITA memberikan rasa dan produk yang berbeda dengan yang yang lainnya baik usaha catering maupun snacknya.

\section{b. Kelemahan (weakness)}

Modal yang dikeluarkan untuk usaha kue tidak terlalu banyak sehingga mampu untuk mendirikan usaha tanpa modal yang besar. Namun walaupun modal milik sendiri, usaha kue juga harus tahu batas waktu kapan kue itu tidak layak unuk di konsumsi. Kue merupakan jenis makanan yang tidak bisa tahan lama sehingga perlu adanya pengaturan waktu dimana kue tersebut dapat untuk di nikmati. Banyak usaha catering dan snack yang berdiri sehingga UMKM MITA mempertahankannya dengan varian jenis kue dan masakan yang berbeda beda agar konsumen tidak bosan.

\section{Analisa Faktor Ekternal}

a. Peluang (oportunity)

Usaha kue ini banyak disukai di berbagai kalangan. Dapat untuk kegiatan rapat, arisan ataupun kegiatan lainnya. Usaha kue yang di jalankan dengan menggunakan sisitem manajemen yang baik walaupun sederhana agar mudah diketahui keuntungan dari hasil penjualan kue, maka akan bisa membuat usaha itu berjalan dengan baik dengan bertahannya usaha maka akan membuat usaha tersebut semakin maju dengan semakin majunya usaha tersebut akan membuat menjadi usaha yang besar, berbagai peluang banyak dimiliki 
dengan terjalinnya kerjasama baik dengan sesama pelaku usaha lain dengan instansi setempat atau kantor kantor disekitarnya usaha berdiri. UMKM MITA perlu adanya manajemen atau administrasi yang teratur dari segi pembukuan atau pencatatan.

\section{b. Ancaman (Treath)}

Pelaku usaha ini adalah usaha yang sejenis banyak berdiri sehingga banyak persaingan namun pelaku usaha ini tidak putus asa karena konsumen mampu memilih mana yang diinginkan sehingga para pelaku usaha ini harus mampu berinovatif atau membuat berkreasi sehingga produk yang dijual berbeda dengan produk lainnya walaupun jenisnya sama. Munculnya pesaing tidak membuat UMKM MITA tersaingi bahkan dalam usaha ini UMKM MITA bermintra dengan UMKM lainnya saat order lebih banyak dengan waktu yang singkat. Walaupun tidak semua order snack atau catering pada UMKM MITA namun kerjasama tetap terjalin.

Adapun penerapan strategi marketing untuk UMKM MITA adalah

1. Segmentasi pasar

Segmentasi pasar ini bagi UMKM

MITA tertuju pada kelompok segala usia karena kue atau semacam roti dapat di nikmati di segala usia dan dalam situasi apapun sangat cocok untuk dinikmati. Faktor dalam segmantasi pasar adalah

a. Segmentasi geografis : masih wilayah di sekitar daerah Tegal.

b. Segmentasi demografis: untuk segala usia

c. Segmentasi psikologis: kebanyakan konsumen yang selalu order untuk kegiatan rapat, seminar pelatiha, arisan

d. Segmentasi perilaku: konsumen yang tertarik dengan produk kue atau catering maka akan order dengan sendirinya.

\section{Penetapan target pasar}

Dengan penentuan target pasar maka UMKM MITA ini berusaha untuk mendapatkan tempat di masyarakat target yang dipilih adalah lingkungan sekolahan, lingkungan perkantoran dan daerah yang jauh dimana daerah tersebut jarang jenis aneka makanan yang tersedia.

\section{Posisi Pasar}

Dengan macam macam kue yang di produksi UMKM MITA dan beraneka macam rasa maka akan menarik konsumen untuk membeli dengan rasa yang kahas di banding dengan produk yang lain, produk kue ini tetap memberikan yang berbeda dan yang berkualitas dan dengan harga yang terjangkau pula.

Strategi pemasaran yang sudah ditetapkan diharapkan untuk merencanakan bauran pemasaran (Marketing Mix) yang terdiri dari semua hal yang dilakukan para pelaku usaha untuk mempengaruhi permintaan akan produk yang terdiri dari $4 \mathrm{P}$ yaitu :

1. Produk (Product)

Pengertian produk menurut Kotler (2002:448) adalah segala sesuatu yang dapat ditawarkan ke pasar untuk memenuhi keinginan atau kebutuhan. Produk yang di jual dipasar merupakan aneka macan yang diinginkan konsumen walaupun jenis dan harganya hampir sama, pelanggan akan memilih produk yang diinginkan. Pada usaha UMKM dengan banyak jenis produk, biasanya terdiri dari satu jenis produk yang unggul di jual, satu produk yang unggul dengan diiringi kualitas yang baik maka produk tersebut akan bertahan.

Perlu adanya produk yang berkualitas agar bisa bersaing dengan produk yang sama. Dengan satu macam produk namun produk tersebut berbeda, menarik dari kemasannya dengan yang lainnya maka akan banyak konsumen mencari produk tersebut. Maka usaha ini harus lebih kreatif dan inovatif agar produk yang di jual dapat bertahan. Produk dari usaha ini mudah dicari dan di peroleh dimana mana. Untuk produk andalan UMKM 
MITA pada snack adalah kue bolen berbagai rasa dan roti berbagai rasa serta catering.

\section{Harga (Price)}

Kotler dan Keller (2009:67) harga adalah salah satu elemen bauran pemasaran yang menghasilkan pendapatan, harga merupakan elemen termudah dalam program pemasaran untuk disesuaikan,fitur produk, saluran dan bahkan komunikasi membutuhkan lebih banyak waktu. Harga merupakan pembayaran yang dilakukan orang untuk memperoleh produk. Harga seharusnya di sesuaikan oleh jenis produk, produk yang bagus maka akan mendapat gharga yang bagus pula, beda dengan produk yang kualitasnya kurang maka hargapun akan berkurang maka harga sangat berkaitan dengan suatu produk. Pada usaha mikro harga dapat dijangkau masyarakat pada umumnya, harga yang bisa dijangkau oleh orang pada umumnya akan memiliki banyaknya konsumen yang akan membeli. UMKM MITA harga pada snack sangat terjangkau untuk 1 dus snack dengan harga $\mathrm{Rp} 6000$ dengan 3 isi sedangkan nasi 1 dus dengan harga $\mathrm{Rp}$ 15.000 .

\section{Tempat (Place)}

Menurut Kotler dan Armstrong (2012:62) yaitu memilih dan mengelola saluran perdagangan yang dipakai untuk menyalurkan produk dan jasa dan juga melayani pasar sasaran, serta mengembangkan sistem distribusi untuk mengirim dan perniagaan produk secara fisik. Lokasi kegiatan usaha, lokasi sangat berpengaruh pada kegiatan usaka, usaha mikro ini banyak bisa kita jumpai di berbagai tempat dengan berbeda beda jenis usaha yang mereka tawarkan namun tetap ada persaingan yang sehat di dalamnya. Banyak pelaku usaha yang mendirikan usaha di rumah rumah atau area sekitar perkantoran, sekolah atau area dekat dengan pasar karena kesusahan untuk mencari lahan untuk usaha. Dirumahpun akan bisa men- jadi tempat usaha yang baik dengan adanya warga disekitarnya bisa juga menjadi pelanggan awal sehingga bisa membaur dengan warga setempat dengan kebersihan dan keindahan tepat usaha yang ditata sedemikian rupa walaupun dirumahpun akan bisa menjadi tempat usaha yang handal. Tempat usaha UMKM MITA masih di rumah belum memiliki outlet.

\section{Promosi (Promotion)}

Boyd (2000:65) mengemukakan pengertian promosi adalah upaya untuk membujuk orang untuk menerima produk, konsep dan gagasan. Aktifitas untuk menyampaikan produk dan membujuk pelanggan untuk membelinya, banyak usaha dengan menyampaikan produknya menggunakan spanduk yang di pasang di tempat mereka berjualan karena dengan seperti memasang spanduk itu mereka bisa memasarkan produk yang mereka jual. Biasanya pada UMKM perhatian yang besar pada pelanggan karena pelanggan juga merupakan promosi yang baik untuk usaha ini. Untuk usaha mikro mungkin belum bisa dengan memberi discount atau pun lainnya namun dengan sikap yang ramah maka pelanggan juga akan merasa nyaman dengan sendirinya pelanggan akan datang. Komunikasi yang baik dan benar akan tepat sasaran. Kegiatan promosi pada UMKM MITA langsung ke kantor atau dinas dalam menawarkan usahanya karna dengan datang menawarkan produk akan lebih mengena.

\section{Hasil analisis strategi pemasaran UMKM MITA}

UMKM MITA adalah salah satu UMKM yang sudah lama berdiri sampai sekarang dengan jemis produk unggulan kue bolen dan roti untuk snacknya serta usaha lainnya catering, untuk snack banyak jenisnya sesuai permintaan konsumen. Sedangkan kue bolen dan roti tiap hari produksi baik untuk pemesanan ataupun untuk dipasarkan. 
Tabel 3. Jenis produk

\begin{tabular}{|l|l|l|}
\hline No & \multicolumn{1}{|c|}{ Jenis produk } & \multicolumn{1}{c|}{ Harga } \\
\hline 1 & Snack 3 isi & $\operatorname{Rp~} 6.000$ \\
\hline 2 & Catering/dus & $\operatorname{Rp~} 15.000$ \\
\hline 3 & Bolen & $\operatorname{Rp~} 1.000$ \\
\hline 4 & Roti & $\operatorname{Rp~} 1.000$ \\
\hline
\end{tabular}

UMKM MITA memperoduksi berbagai macam jenis kue dan masakan sesuai pesanan dari hasil usaha tersebut UMKM MITA menghasilkan pendapatan, Pada tahun 2017 secara keseluruhan pendapatan tercatat sebesar Rp 112.899.000, pada tahun 2018 pendapatan secara keseluruhan sebesar Rp 125.443.500, sedangkan pada tahun 2019 sebesar Rp 147.580.500, di tahun 2020 mengalami penurunan karena pandemi corona yang terjadi. Namun pendapatan UMKM MITA tidak hanya pada produk snack atau masakan, UMKM MITA juga menyewakan alat presmanan dan pelatihan boga.

\section{Tabel 4 data pendapatan} Tahun 2017-2019

\begin{tabular}{|c|c|c|}
\hline Tahun & $\begin{array}{c}\text { Pndapatan } \\
\text { operasi }\end{array}$ & $\begin{array}{c}\text { Pendapatan } \\
\text { non operasi }\end{array}$ \\
\hline 2017 & 112.889 .000 & 13.081 .500 \\
\hline 2018 & 125.443 .500 & 14.535 .000 \\
\hline 2019 & 147.580 .500 & 17.100 .000 \\
\hline
\end{tabular}

Produk yang dijual pada tahun 2017-2018 antara lain :

Tabel 5 jenis produk

\begin{tabular}{|c|c|}
\hline No & Jenis produk \\
\hline 1 & Snack /dus \\
\hline 2 & Catering/dus \\
\hline 3 & Roti \\
\hline 4 & Bolen \\
\hline
\end{tabular}

Hasil penjualan mengalami peningkatan dari tahun 2017-2018 adapun peningkatan tersebut sebesar Rp 12.554.500 untuk penjualan produk sedangkan untuk pendapatan non produk sebesar $\mathrm{Rp}$ 1.453 .500
Tabel 6 data kenaikan pendapatan

\begin{tabular}{|c|c|}
\hline Tahun & $\begin{array}{c}\text { Total kenaikan } \\
\text { pendapatan operasi }\end{array}$ \\
\hline $2017-2018$ & Rp 12.554.500 \\
\hline Tahun & $\begin{array}{c}\text { Total kenaikan } \\
\text { pendapatan non } \\
\text { operasi }\end{array}$ \\
\hline $2017-2018$ & $\mathrm{Rp} 1.453 .500$ \\
\hline
\end{tabular}

Produk yang dijual pada tahun 2018-2019 antara lain :

Tabel 7 jenis produk

\begin{tabular}{|c|c|}
\hline No & Jenis produk \\
\hline 1 & Snack/dus \\
\hline 2 & Catering/dus \\
\hline 3 & Roti \\
\hline 4 & Bolen \\
\hline
\end{tabular}

Hasil penjualan mengalami peningkatan dari tahun 2018-2019 adapaun peningkatan tersebut sebesar Rp 22.137.000 untuk penjualan produk sedangkan untuk pendapatan non produk sebesar $\mathrm{Rp}$ 2.565.000.

Tabel 8 data kenaikan pendapatan

\begin{tabular}{|l|l|}
\hline Tahun & $\begin{array}{l}\text { Total kenaikan penda- } \\
\text { patan operasi }\end{array}$ \\
\hline $2018-2019$ & Rp 22.137.000 \\
\hline Tahun & $\begin{array}{l}\text { Total kenaikan penda- } \\
\text { patan non operasi }\end{array}$ \\
\hline $2018-2019$ & Rp 2.565.000 \\
\hline
\end{tabular}

Dari data di atas dapat disimpulkan bahwa UMKM MITA memiliki kenaikan tiap tahunnya dari segi penghasilan dari tahun 2017 - 2018 mengalami kenaikan sebesar Rp Rp 12.554.500 dan pada tahun 2018 - 2019 juga mengalami kenaikan Rp 22.137.000. sehingga dapat disimpulkan bahwa UMKM MITA dengan strategi yang dimiliki mengena pada sasaran atau sesuai dengan tujuannya. Dari usaha memproduksi snack dan catering merupakan paduan yang sempurna juga promosi yang dijalankan melalui door to door dari kantor yang satu ke kantor lainnya atau dari sekolah yang satu ke sekolah yang lainnya berjalan sangat efektif walaupun sudah 
berjalan efektif UMKM MITA terus mengembangkan usahanya dengan terus berinovasi dengan berbagai jenis snack dan masakan yang di tawarkan. Perpaduan catering dengan snack membuat UMKM MITA memiliki pendapatan lain yaitu dari penyewaan alat presmanan juga pelatihan boga sehingga ini dapat menambah keuntungan bagi UMKM MITA.

\section{KESIMPULAN}

Sesuai dengan judul dan tujuan penelitian serta telah diuraikan mengenai lokasi penelitian serta analisa SWOT yang sudah diuraikan secara mendalam. Pada kegiatan UMKM memiliki faktor internal yaitu kekuatan meliputi kemampuan internal atau sumber daya manusia dalam hal ini UMKM MITA memiliki berbagai jenis kue atau masakan dan masih terus berinovasi agar tetapdi terima di pasaran. Sedangkan faktor internal yang kedua adalah kelemahan. Untuk kelemahan pada usaha ini adalah tidak tahan lama dari kue yang di produksi sehingga dalam memproduksi wajib menentukan kapan kue tersebut layak untuk di konsumsi pada UMKM MITA untuk produksi snack sesuai permintaan yang terjadi setiap harinya begitu juga dengan catering sesuai pesanan yang ada.

Faktor ekternal yang pertama adalah peluang, peluang dari usaha kue dapat di konsumsi semua kalangan dengan harga yang terjangkau juga dapat di konsumsi semua orang, peluang yang dimiliki usaha ini yaitu usaha yang di jalankan dengan menggunakan sistem manajemen yang baik walaupun sederhana akan bisa membuat usaha itu berjalan dengan baik UMKM MITA masih menggunakan manajemen yang sederhana. Adapun ancaman bagi pelaku usaha ini adalah usaha yang sejenis banyak berdiri sehingga banyak persaingan namun pelaku usaha ini tidak putus asa. Pesaing dalam dunia usaha pasti ada tetapi jika produk yang ditawarkan berbeda dan memiliki nilai lebih maka akan dicari konsumen. Pada UMKM
MITA bermintra dengan UMKM lainnya sehingga ada kerja sama antara UMKM MITA dengan UMKM lainnya.

Dari uraian hasil penelitian dapat disimpulkan bahwa usaha UMKM mampu bertahan dalam kondisi apapun, dan mampu bersaing dengan usaha yang lebih maju. Karena UMKM dalam memilih produk tidak memerlukan bahan impor atau bahan yang digunakan untuk menciptakan produk ada di sekitar kita sehingga penjualan terus berjalan tanpa adanya kekurangan bahan untuk produksi. Dalam UMKM selalu ada persainga karena produk yang dijual memang banyak jenisnya karena mudah untuk dibuat dan dengan modal yang sedikit sehingga siapapun akan mampu untuk membuat dan menjualnya.

\section{SARAN}

Menerapkan program loyalitas pelanggan untuk menjaga kesinambungan sehingga adanya ikatan yang erat antar penjual dan pembeli. Menjaga kebersihan tempat usaha sehingga keadaan sekitar yang bersih akan menambah keindahan sehingga pelanggan nyaman dalam membeli produk, untuk orang yang memiliki usaha sendiri juga harus menjaga kebersihan diri sendiri sangat penting sehingga dalam melaksanakan kegiatan usahanya dalam keadaan sehat. Serta melengkapi atau menambahkan produk yang dijual sesuai keinginan pelanggan. menambahkan perlengkapan yang masih kurang sehingga kelengkapan atau penambahan produk yang dijual tersebut dapat menunjang pelanggan tetap setia.

Dengan berwirausaha setidaknya menciptakan lapangan kerja bagi diri sendiri dan lingkungan sekitarnya, dengan mampu menciptakan usaha bagi orang lain maka akan membantu perekonomian nasional. Banyak orang menginginkan usaha milik sendiri dibanding memiliki pekerjaan diluar kota. Dengan banyaknya usaha yang semakin mendukung akan mengurangi jumlah pengangguran yang ada dinege- 
ri ini juga akan mengurangi jumlah urbanisasi.

\section{DAFTAR PUSTAKA}

Analisis Strategi Pemasaran Untuk Meningkatkan daya Saing UMKM, diakses pada tanggal 10 Mei 2020 dari http://www.neliti.com.

Dimas, HW. Zainul,A. \& Sunarti (2015). Strategi Pemasaran Untuk Meningkatkan Daya Saing UMKM (studi pada BatikDiajeng Solo). Administrasibisnis.studentjournal.u b.ac.id.

Fitriani, N. I., Sari, I. A., \& Raharjo, T. B. (2019). Analisis Perbedaan Penerimaan Pajak di KPP Pratama Tegal Menggunakan Peraturan Pemerintah Nomor 46 Tahun 2013 Dengan Peraturan Pemerintah Nomor 23 Tahun 2018. Permana : Jurnal Perpajakan, Manajemen, Dan Akuntansi, 11(1), 63-76. https://doi.org/10.24905/permana.v $\underline{11 \mathrm{i} 1.28}$

Iklan Baris UMKM, diakses pada tanggal 12 Mei 2020 dari http://www.iklanbarisumkm.blogspot.com.

Konsep Strategi Pemasaran dan Bauran Pemasaran 4P ( Marketing Mix), diakses pada tanggal 15 Mei 2020 dari http://www.kembar.pro.

Lestari, I. S., \& Amirah. (2017). Pengaruh Tingkat Suku Bunga, Capital Adequacy Ratio, Non Performance Loans dan Loan To Deposit Ratio terhadap Penyaluran Kredit UMKM. Permana : Jurnal Perpajakan, Manajemen, Dan Akuntansi, 9(1), 81-97. Retrieved from

https://permana.upstegal.ac.id/inde x.php/permana/article/view/140
Lima Pengertian Segmentasi Pasar Menurut Para Ahli diakses pada tanggal 17 Mei 2020 dari http://www.gilabisnis.com.

Lima Strategi Pemasaran Yang Efektif Untuk UMKM, diakses pada tanggal 15 Mei 2020 dari http://www.whello.id.

Pemasaran, Pendapatan diakses pada tanggal 15 Mei 2020 dari http:/www.id.m.wikipedia.org.

Pengertian dan Jenis Metode Deskriptif, diakses pada tanggal tanggal 17 Mei 2020 dari http://www.idtesis.com.

Pengertian Pemasaran, diakses pada tanggal 17 Mei 2020 dari http://www.ilmu-ekonomi-id.com

Pengertian UMKM, diakses pada tanggal 8 Mei 2020 dari http://www.idcloudhost.com.

Pengertian Pendapatan, diakses pada tanggal 17 Mei 2020 dari http://www.cekkembali.com.

Pengertian Strategi Pemasaran, diakses pada tanggal 15 Mei 2020 dari http://www.guruakuntansi.com.

Philip Kotler \& Gary Armstrong.2008, Prinsip - prinsip Pemasaran. Edisi dua belas. Jakarta :Erlangga Jakarta.

Positiong dan Deferensiasi, diakses pada tanggal 11 Juli 2020 dari http://www.erenmikasa.wordpress. com.

Segmentation, Targeting, Positioning dan Perilaku konsumen, diakses pada tanggal 20 Mei 2020 dari http://www.faizfzz.wordpress.com.

Sri Lestari Triyaningsih (2012). Strategi pemasaran Usaha Kecil Dan 
Menengah. Jurnal ekonomi dan kewirausahan. Vol 12. No. 12012. $37-46$

Strategi Pemasaran, dan pengertian Pemasaran diakses pada tanggal 17 Mei 2020 dari http://www.maxmanroe.com.

Strategi Pemasaran Usaha Kecil dan Menengah, diakses pada tanggal $17 \quad$ Mei 2020 dari http://www.media.neliti.com.

Strategi Pemasaran Yang Efektif diakses pada tanggal 15 Mei 2020 dari http://www.jurnal.id.

Tips Jitu Menyusun Strategi Pemasaran Usaha Kecil, diakses pada tanggal 15 Mei 2020 dari http://www.bisnisukm.com.

UMKM Malang Raya, diakses pada tanggal 9 Mei 2020 dari http://www.umkmmalangraya.blog spot.com 